\title{
Ammunition to Immunotherapy: The "Nobel" Journey
}

On a pleasant evening in a small town of Vienna, in the year 1876, a 43-year-old sophisticated, rich, and genius gentleman met a beautiful salesgirl in a florist shop. He fell in love with her and offered her an apartment in Paris. The girl was illiterate and the man was well-educated, who entreated her to at least learn the conversational French. She did not like it, and so the love failed to translate into marital lock. ${ }^{[1]}$

This was Alfred Bernhard Nobel, and the girl was Sofie Hess, his "first love." Bertha Von Suttner was Alfred's "second great love." She was a well-educated woman, musically gifted and multilinguist. They discussed war and peace and had widely opposite opinions on these two issues. She favored peace through conversation and compromises, but Alfred believed in powerful weapons for protection against enemies. Due to this reason, i.e., totally divergent views on arms, their relationship did not turn into nuptial alliance. The girl found some other guy to marry with. ${ }^{[1]}$

Alfred Nobel will always be remembered as one of the most successful pioneers and inventors the World has ever seen, but he was not as successful when it came to love. Albeit, he was so kind-hearted that he supported Sofie financially, for the rest of her life. Analogously, despite a great setback, Alfred had a good relationship with both Bertha and her husband. Alfred remained unmarried for his entire life and Bertha became the first woman to receive the Noble Peace price in 1905. ${ }^{[1]}$

Alfred Nobel (October 21, 1833-December 10, 1896) was a Swedish chemist, engineer, inventor, writer, poet, businessman, polyglot, philanthropist, and held 355 different patents on his name. An element "nobelium" was named after him. He invented dynamite, manufactured Bofors and established 90 ammunition companies, some of which are still functional. ${ }^{[2]}$ Nitroglycerine (NTG), an unstable explosive, was invented in 1847, by Sobrero. Nobel got inspired by the invention, while Sobrero himself opposed its use. After losing one of his brothers in an explosion through NTG in Stockholm, his quest for safer and controllable explosives got amplified to the extent that after 20 years of persistent hard work, in 1867, Nobel invented "dynamite," a substance easier and safer to handle than the more unstable NTG. His boisterous efforts went on to invent "gelignite" in 1875 and patent "ballistite" in 1887 (a predecessor of cordite), each more stable and powerful than dynamite. Nobel also invested in the Caspian Sea oilfield business of his brothers and amassed great wealth. ${ }^{[3]}$
"Le marchand de la mort est mort." This was the headline of most of the newspapers in 1888, when they mistakenly published obituaries of Alfred, which meant "The merchant of death is dead." Indeed, at that time, his brother Ludvig had died. ${ }^{[4]}$ Alfred was dismayed by imagination of himself being remembered like this. He planned an intelligent way to leave a better legacy behind. On November 27, 1895, Alfred Nobel signed his last will and testament, giving $94 \%$ of his property to a series of prizes, to "the person (s) who shall have made the most important discovery within the domains of Physics, Chemistry, Physiology or Medicine, Literature and Peace. "[5]

On December 10 every year, at the Nobel Prize distribution ceremony, the elected candidates receive three things: A Nobel diploma, a Nobel Medal, and a document confirming the Nobel Prize amount. Each Nobel diploma is a specially designed certificate, created by traditional Swedish and Norwegian artists and calligraphers. The Nobel Medals are handmade with perfection and in 18 carat gold. Alfred Nobel had allocated more than Swedish Kronor (SEK) 31 million (today approximately SEK 1702 million, equal to 1345 crore INR) as Nobel fund, which was invested in "safe custodies." The Nobel Prize amount for 2018 was set at SEK 9.0 million (7.1 crore INR) per full Nobel Prize. ${ }^{[6]}$ The word "Laureate" refers to Greek god Apollo's laurel wreath. In Ancient Greek, athletic and poetry competition winners were awarded laurel wreaths, as a sign of honor. ${ }^{[6]}$

On December 10, 1901, the Nobel Prizes were awarded for the first time. Between 1901 and 2018, a total of 590 Nobel Prizes have been awarded. As per Nobel foundation, the prize amount can be equally divided to a maximum of three awardees (the rule of three). If none of the nominees is found to be worthy, the prize is reserved for next year. If, even then, the prize cannot be awarded, the amount is added to the Foundation's restricted funds. Since the start, there are 49 times when the Nobel Prizes have not been awarded, most of them during World War I and II. Since 1974, posthumously awarding of Nobel Prizes has been stopped, unless death has occurred after the announcement. Before 1974, it was awarded twice posthumously. ${ }^{[6]}$

The youngest person to receive this award is Malala Yousafzai, in 2014. She received this for "peace" at the age of 17 years. The eldest Nobel laureate has been Arthur Ashkin in Physics in 2018, at 96 years. The Curies were a very successful "Nobel Prize family." Marie Curie herself was awarded two Nobel Prizes. Till now, 109 Nobel Prizes in Physiology or Medicine have been awarded. In 1923, Frederick G. Banting became the youngest Nobel Laureate in Physiology or Medicine, at 32 years. The oldest Nobel 
Laureate in Physiology or Medicine was Peyton Rous, at 87 years, who received prize in 1966. Adolf Hitler forbade German Nobel Laureate Gerhard Domagk from accepting the Nobel Prize, in Physiology or Medicine, in 1939. Nobel Prize nominations are highly secret phenomenon. The nomination database is kept secret for 50 years. Interestingly, the Austrian neurologist and the father of psychoanalysis Sigmund Freud (1856-1939) was nominated 32 times in Physiology or Medicine, but never awarded. He was also nominated once in Literature stream. ${ }^{[6]}$

The world's most prestigious award is not devoid of controversies. To begin with, the founder himself had a tainted public image, having become rich by finding ways to kill more people faster than ever before. By 2014, out of 864 people, only 47 were women, reflecting gender discrimination somewhere. The most-contentious Nobel peace prize of 1994 is arguably the one for Palestine Liberation Organization leader Yasser Arafat, for whom the critics opine that Arafat was head of Fatah, a "so called" terrorist group. Surprisingly, Adolf Hitler was also nominated for a peace prize, although the nomination was quickly withdrawn. Two winners have voluntarily declined the most sought-after award. Jean-Paul Sartre did not accept the 1964 literature prize. In 1974, he was joined by Le Duc Tho, who was declared the peace prize winner for his work to end the Vietnam War. Tho, however, refused to accept it, saying that "peace has not yet been established." Hitler's ire erupted over Nobel prizes when a German journalist Carl von Ossietzky, a critic of Hitler, won the 1935 peace prize. Consequently, Hitler barred all Germans from accepting a Nobel Prize and created the German National Prize for Art and Science as an alternative. In 2008, Harald Zur Hausen received the prize for physiology or medicine for his discovery of the human papilloma virus (HPV) and its link to cervical cancer. The jury panel had ties to AstraZeneca, a company producing HPV vaccine, underscoring an apparent conflict of interest. ${ }^{[7]}$ Ironically, there is also a controversy attached with Nobel laureates of 2018 in Physiology or Medicine. Although the research of Allison and Honjo is linked to a revolutionary progress in the cancer therapy, some critics say that they were not the only researchers to play a crucial role in the development of checkpoint inhibitors, but there are many others. As per a section of the media, experts in cancer immunotherapy were "shocked" that the Nobel announcements in 2018 excluded at least three researchers who were major contributors to the research on immunotherapy: Freeman of Harvard Medical School, Lieping Chen of Yale University, and Arlene Sharpe of Harvard Medical School. Freeman reportedly said he was "disappointed not to be recognized for his contributions," adding that his and Sharpe's "discoveries were foundational." Chen disagrees with "the rule of three" and says it causes "many scientists spend a lot of time promoting themselves, rather than doing discovery to solve the problem." On being asked about the possible oversight, members of the Nobel committee said they were willing to discuss the laureates, but would not answer questions about scientists who had not been chosen. ${ }^{[8]}$

Immunotherapy is now considered one of the five pillars cancer therapy, namely, surgery, radiation, chemotherapy, precision medicine, and immunotherapy. The 2018 Nobel Prize in Physiology or Medicine has been awarded jointly to two cancer immunotherapy researchers, James P. Allison, $\mathrm{PhD}$, of The University of Texas MD Anderson Cancer Center, and Dr. Tasuku Honjo of Kyoto University in Japan. Both researchers are being recognized for their work since 1990s. In his laboratory at the University of California, Berkeley, Allison studied the cytotoxic T-cell antigen and its role in suppressing the immune response against cancer cells. Honjo, at Kyoto University in Japan, discovered programmed death receptor (PD-1) and its binding to the ligand on cancer cells, PD-L1. Their work concluded that these checkpoints can be antagonized to rejuvenate the body's immunity against cancer cells. ${ }^{[9]}$ "Better late than never," the 'Nobel' recognition to this landmark research is quite late, notwithstanding the fact that immune checkpoint inhibitors have already been approved and are in clinical use since $2011 .^{[10]}$

\section{Financial support and sponsorship}

Nil.

\section{Conflicts of interest}

There are no conflicts of interest.

HS Darling

Department of Medical Oncology and Hemato-oncology, Narayana Superspeciality Hospital, Gurugram, Haryana, India

Address for correspondence: Dr. HS Darling, Narayana Superspeciality Hospital, Gurugram - 122 002, Haryana, India. E-mail:doc_iaf@yahoo.com

Submitted: 05-Apr-2019 Revised: 22-Jul-2019 Accepted: 19-Sep-2019 Published: 17-Feb-2020

\section{References}

1. Available from: https://www.visitvarmland.se/en/ alfred-nobel-multi-faced-innovator-and-citizen-world. [Last accessed on 2019 Jan 20].

2. BBC - History - Historic Figures: Alfred Nobel (1833-1896) [Internet]. Available from: http://www.bbc.co.uk/history/historic figures/nobel_alfred.shtml. [Last cited 2019 Oct 9].

3. LeVine, Steve: The Oil and the Glory Random House; 2007. p. 33-34. ISBN 978-0-375-50614-7 
4. Alfred Nobel Was Also Known as "The Merchant of Death" [Internet]. Available from: http://www.todayifoundout.com/index. php/2011/01/alfred-nobel-was-also-known-as-the-merchant-ofdeath/. [Last cited 2019 Oct 9].

5. Full text of Alfred Nobel's will [Internet]. NobelPrize.org. Available from: https://www.nobelprize.org/alfred-nobel/full-textof-alfred-nobels-will-2/. [Last cited 2019 Oct 9].

6. LAUREATE $\mid$ meaning in the Cambridge English Dictionary [Internet]. Available from: https://dictionary.cambridge.org/ dictionary/english/laureate. [Last cited 2019 Oct 9].

7. Nobel Prize Scandals | Britannica.com [Internet]. Available from: https://www.britannica.com/list/7-nobel-prize-scandals. [Last cited 2019 Oct 9].

8. Were 3 scientists "snubbed" by the Nobel Prize in medicine? Advisory Board Daily Briefing [Internet]. Available from: https:// www.advisory.com/daily-briefing/2018/10/04/nobel-prize. [Last cited 2019 Oct 9].

9. Nobel Prize Awarded to Cancer Immunotherapy Researchers [Internet]. Available from: https://www.cancer.org/latest-news/ nobel-prize-awarded-to-cancer-immunotherapy-researchers.html.
[Last cited 2019 Oct 9].

10. Timeline of Progress in Immunotherapy - Cancer Research Institute [Internet]. Available from: https://www.cancerresearch. org/immunotherapy/timeline-of-progress. [Last cited 2019 Oct 9].

This is an open access journal, and articles are distributed under the terms of the Creative Commons Attribution-NonCommercial-ShareAlike 4.0 License, which allows others to remix, tweak, and build upon the work non-commercially, as long as appropriate credit is given and the new creations are licensed under the identical terms.

\begin{tabular}{|l|l|}
\hline \multicolumn{2}{|c|}{ Access this article online } \\
\hline Quick Response Code: & Website: \\
& www.ijmpo.org \\
\cline { 2 - 2 } & DOl: \\
\hline
\end{tabular}

How to cite this article: Darling HS. Ammunition to immunotherapy: The "Nobel" journey. Indian J Med Paediatr Oncol 2019;40:581-3. 